\title{
Nilai-Nilai Feminisme Guru Taman Kanak-Kanak
}

\author{
Faradila
}

\author{
Nursalam \\ Universitas Muhammadiyah Makassar \\ nursalam@unismuh.ac.id
}

\author{
Syarifuddin \\ Universitas Muhammadiyah Makassar \\ syarifuddin@unismuh.ac.id
}

\begin{abstract}
ABSTRAK
Penelitian ini bertujuan untuk mengetahui bagaimana pandangan masyarakat terhadap nilai-nilai feminisme yang dimiliki guru taman kanak-kanak di Kecamatan Bone-Bone Kabupaten Luwu Utara dan bagaimana proses penanam nilai-nilai yang dilakukan guru Taman Kanak-Kanak terhadap peserta didiknya. Metode penelitian adalah penelitian kualitatif deskriptif. Dengan penelitian ini diharapkan dapat mengungkap berbagai informasi kualitatif dengan deskripsi-analisis yang teliti dan penuh makna, yang juga tidak menolak informasi kuantitatif dalam bentuk angka maupun jumlah. Strategi yang digunakan dalam penelitian ini adalah studi kasus (case study). Karena permasalahan dan fokus penelitian sudah ditentukan dalam proposal sebelum terjun ke lapangan, maka jenis strategi penelitian ini secara lebih spesifik dapat disebut sebagai studi kasus terpancang (embedded case study research). Hasil penelitian ini menunjukkan bahwa nilai-nilai feminisme telah memperbaiki posisi perempuan dalam masyarakat dan pemberian hak perempun. Pandangan setiap masyarakata terhadap sosok seorang guru akan berbedah-bedah tegantung darimana kita mengambil sudut pandang. Dengan sifatsifat kewanitaan dan keibuannya seorang guru taman kanak-kanak mampu membentuk karakter anak didiknya, mengembangkan keterampilan dasar dan dasar-dasar pemahaman dalam semua bidang mampu memenejemen kelas. Dalam proses penanaman nilai-nilai pada anak, pendidikan moral disisipkan secara terstruktur dalam proses pembelajaran yang dilaksanakan. Guru memiliki peran yang sangat penting dalam menentukan kuantitas dan kualitas pembelajaran yang dilaksanakannya.
\end{abstract}

Kata Kunci: Nilai, Feminisme, Guru

\section{PENDAHULUAN}

Beberapa tahun belakangan ini istilah gender menjadi bahan perbincangan yang hangat di berbagai forum dan media, formal maupun informal. Hampir setiap bidang pembangunan menganjurkan dilaksanakannya analisis gender dalam komponen program. Namun, tidak sedikit pula yang masih menganggap bahwa gender adalah sama dengan jenis kelamin atau lebih sempit lagi gender sama dengan perempuan. Hal ini tidak mengherankan mengingat memang lebih banyak kaum perempuan yang mendapat dampak dari ketidakadilan gender dalam lingkungan keluarga maupun masyarakat, dari pada kaum laki-laki. Pada dasarnya semua orang sepakat bahwa perempuan dan laki-laki 
berbeda. Namun, gender bukanlah jenis kelamin laki-laki dan perempuan sebagai pemberian Tuhan. Gender lebih ditekankan pada perbedaan peranan dan fungsi yang ada dan dibuat oleh masyarakat. Oleh karena itu, gender penting dipahami dan dianalisis untuk melihat apakah perbedaan tersebut menimbulkan diskriminasi dalam artian perbedaan yang menimbulkan diskriminasi dalam artian perbedaan yang membawa kerugian dan penderitaan terhadap pihak perempuan.

Perempuan dalam konteks sosiologi saat ini memang dapat dipisahkan menjadi 2 dimensi. Dimensi yang pertama adalah perempuan sebagai sex (jenis kelamin) yang merupakan sesuatu yang bersifat kodrati. Sedangkan dimensi kedua adalah perempuan sebagai sebuah citra yang merupakan hasil konstruksi sosial yang ada. Dimensi yang kedua inilah yang saat ini disebut dengan istilah gender, walaupun istilah gender sendiri baru masuk ke Indonesia pada awal 90-an.

Pengertian gender diartikan sebagai interpretasi mental dan cultural terhadap perbedaaan kelamin yakni laki-laki atau pria dan perempuan/wanita. Gender adalah suatu konsep kultural yang berupaya membuat pembedaan dalam hal peran, perilaku, mentalitas, dan karakteristik emosional antara pria dan wanita yang berkembang dalam masyarakat. Gender biasanya dipergunakan untuk menunjukkan pembagian kerja yang dianggap tepat bagi pria dan wanita adalah suatu sifat yang melekat pada kaum pria dan kaum wanita, yang dikonstruksi secara sosial maupun cultural. Sifat-sifat gender untuk kaum wanita adalah: cantik, lemah lembut, emosional, dan keibuan, dan tugas utama wanita sepanjang hidupnya adalah melahirkan menyusui, dan segala aktivitas yang berkaitan dengan pengasuhan anak, dan pekerjaan-pekerjaan yang dapat diselesaikan di sekitar rumah. Sedangkan sifat gender untuk kaum pria adalah: kuat, rasional, jantan, dan perkasa dengan tugas utama melindungi keluarga dari bahaya luar dan mencari nafkah ke luar rumah Sifat-sifat itu dapat saling dipertukarkan sesuai waktunya, tempatnya, atau kelasnya. Dengan semakin majunya tingkat pendidikan wanita dan pergeseran normanorma serta nilai-nilai budaya dan dampak semakin tingginya jumlah wanita yang berperan ganda, yaitu sebagai ibu dan tenaga kerja, maka dalam kehidupan berkeluarga masa kini wanita memiliki kedudukan yang setara dengan pria. Seorang isteri tidak hanya tinggal di rumah, tetapi juga sebagai pendamping suami yang seringkali pula harus bekerja untuk mencukupi kehidupan keluarga yang tuntutan kehidupan keluarga semakain kompleks. Dengan pergeseran norma tersebut menuntut konsekuensi terhadap pembagian peran yang telah berjalan dan mengakar selama ini seperti disebutkan di atas. 
Feminisme lahir dengan tujuan mencari keseimbangan antara laki-laki dengan perempuan. Feminisme merupakan gerakan perempuan untuk menolak sesuatu yang dimarginalisasikan, direndahkan, dinomorduakan, dan disubordinasikan oleh kebudayaan, sosial, balk dalam bidang publik maupun bidang domestik. Dengan lahirnya gerakan feminisme ini, masyarakat mulai terbuka dan sadar akan kedudukan perempuan yang inferior. Gerakan feminisme yang diwarnai oleh tuntutan kebebasan dan persamaan hak agar parsamaan perempuan dapat menyarnai laki-laki dalam bidang sosial, pendidikan. telah banyak perempuan yang masuk kedunia maskulin dan berkiprah bersama-sama lakilaki. Sehingga banyak orang awam melabel feminisme dengan negatif. Feminisme merupakan kajian sosial yang melibatkan kelompok-kelompok perempuan yang memberikan sumbangsi pendidikan. Feminisme bukan merupakan upaya pemberontakan terhadap laki-laki, bukan upaya melawan pranata sosial, budaya seperti perkawinan, rumah tangga, maupun bidang publik. kaum perempuan pada intinya tidak mau dinomorduakan, tidak mau dimarginalkan.

Dalam era globalisasi pembangunan nasional pada konteks sumber daya manusia, keterlibatan perempuan merupakan hal yang sangat esensial. Oleh sebab itu, kepedulian holistik yang melihat sumber daya perempuan denga peran khalifahannya di muka bumi dengan acuan pada nilai-nilai agama dan nilai luhur budaya bangsa, perlu di sinergikan dalam konteks dimensi publik dan domestik sekaligus. Dimensi publik menyangkut aspek perempuan di bidang iptek, ekonomi, ketenagakerjaan, politik dan ketahanan nasional. Dimensi domestik mencakup aspek kesejahteraan keluarga, kesehatan, hubungan keluarga yang simentris dan lain sebagainya. Dalam rangka mencapai keberhasilan pembentukan kepribadian anak agar mampu diwarnai dengan nilai-nilai agama, maka perlu didukung oleh unsur keteladanan dari orang tua dan guru. Untuk tujuan tersebut dalam pelaksanaannya gum dapat mengembangkan strategi pembelajaran secara bertahap dan menyusun program kegiatan seperti program kegiatan rutinitas, program kegiatan terintegrasi dan program kegiatan khusus. Dengan demikian, pendidikan anak itu merupakan modal terbesar yang dimiliki bangsa untuk mewujudkan cita-cita bangsa kelak. Berhasil atau tidaknya langkah yang sudah kita rintis ini sangat bergantung pada generasi penerus kita nanti. Oleh karena itu, kita seharusnya sedapat mungkin mengupayakan agar si penerus ini tumbuh dan berkembang seoptimal mungkin, sehingga mereka kelak akan mampu mewujudkan apa yang diinginkan bangsa dengan tepat bahkan lebih dari apa yang kita harapkan, dan karena itulah anak sejak kecil sudah hams diberikan pendidikan. 
Taman Kanak-kanak merupakan lembaga pendidikan prasekolah dengan masa program belajar paling lama tiga tahun menjelang anak berusia enam tahun yang merupakan satu kesatuan. Ketentuan mengenai pelaksanaan Taman Kanak-kanak sebagai persyaratan untuk memasuki Sekolah Dasar.

Mendidik anak di Taman Kanak-Kanak berbeda dengan mendidik anak SD. Mendidik anak Taman Kanak-Kanak sangat sulit, butuh kesabaran dan keuletan. Ciri-ciri pertumbuhan kejiwaan anak Taman Kanak-Kanak berbeda dengan ciri-ciri kejiwaan anak Sekolah Dasar, menengah dan orang dewasa. Inilah yang membuat strategi pendidikan anak Taman Kanak-Kanak berbeda dengan strategi pendidikan Sekolah Dasar atau jenjang persekolahan yang lain. Anak Taman Kanak-kanak mempunyai sifat yang bermacam-macam ada yang pendiam, ada yang keras, ada yang nakal, ada pula yang super nakal (Hiper). Apalagi anak sudah terpengaruh dengan adegan-adegan TV,Games. Ini sangat berbahaya sekali, yang jelas orang tua harus mengontrol apa yang dilihat oleh anaknya..

Guru sebagai pendidik yang secara langsung mampu tidak langsung mendapat tugas dari orang tua atau masyarakat untuk melaksanakan pendidikan. Anak didik membutuhkan pertolongan dan bimbingan baik jasmani maupun rohani. Guru harus memberikan jalan yang terbaik untuk anak didiknya. Sebagai manapun keadaannya, guru harus sabar menghadapinya. Dan berusaha semaksimal mungkin untuk memberikan pertolongan dan bimbingan. Sebagaimana disebutkan dalam Garis Besar Haluan Negara (GBHN) bahwa wanita merupakan mitra sejajar pria di segala kehidupan. Melalui GBHN tersebut secara tersurat wanita Indonesia diharapkan mampu memerankan tugas-tugas berikut secara simultan dan berkesinambungan. 1) Wanita Indonesia mampu berperan sebagai isteri yang mendampingi suami dan menopang karir suami, 2) Wanita Indonesia mampu berperan sebagai pengatur rumah tangga, 3) Wanita Indonesia mampu berperan sebagai ibu yang mampu mendidik dan membina generasi muda, baik rohani maupun jasmani, 4) wanita Indonesia mampu berperan sebagai tenaga kerja yang mampu menambah pendapatan keluarga untuk mencapai keluarga sehat sejahtera, 5) Wanita Indonesia mampu berperan sebagai anggota masyarakat yang aktif dalam kegiataN sosial, 6) Wanita Indonesia mampu berperan sebagai manusia pembangunan yang berkemampuan mengembangkan karir dan profesinya. Di dalam kehidupan berkeluarga masalah pengasuhan dan pendidikan anak pada umumnya dititik beratkan pada peran seorang ibu yang paling bertanggung jawab. Pendidikan anak tidak hanya diperlukan agar anak dapat menyesuaikan diri dengan tuntutan masa kini, melainkan juga terhadap 
tuntutan masa depan. Dengan demikian diharapkan orang tua dapat membina anak menjadi cerdas, terampil, dan kreatif serta mandiri, sehingga kelak menjadi daya manusia yang tangguh.

Posisi kunci dalam pembinaan anak terutama masa balita adalah di tangan ibunya. Pada usia muda ini hampir seluruh waktu anak berada di dekat ibu dan anak sangat tergantung kepadanya. Sebagai pengasuh dan pendidik anak dalam keluarga, ibu mempengaruhi pertumbuhan dan pengembangan anak-anaknya, baik secara potitif maupun negatif, karena dalam berinteraksi dengan anak seorang ibu dapat memainkan peran sebagai:

a. Pengawas dan pengatur rumah tangga,

b. Pengamat yang baik,

c. Sumber pengarah,

d. Sumber pendorong dan penghibur,

e. Membahas,

f. Teman main dan teman ceritera.

Ibulah yang mengetahui kebutuhan anak, dengan memperhatikan secara seksama perubahan yang terjadi pada anak, kebutuhan anak akan sandang, pangan kesehatan, perhatian dan kasih sayang, rasa aman, serta rangsangan mental, emosional, dan sosial akan dapat dipengaruhi oleh ibu. Maka anak akan merasa aman, terlindungi dan percaya pada lingkungan. Hal ini penting untuk kehidupan emosional anak yang akan menjadi titik tolak dan sekaligus landasan bagi jenjang tumbuh kembang anak selanjutnya.

Sebuah citra yang telah terbangun dan melekat dalam pandangan masyarakat bahwa guru Taman Kanak-Kanak lazimnya adalah wanita. Guru Taman Kanak-Kanak mayoritas wanita sebab wanita memiliki sifat lemah lembut, sabar, keibuan, dan dalam membimbing anak dengan penuh kasih sayang. Dengan demikian maka anak-anak akan merasa nyaman dalam belajar di sekolah meskipun tanpa didampingi oleh ibunya sendiri.

Berlandaskan konsep tersebut, maka peran wanita sangat jelas dalam menumbuhkembangkan anak di awal pertumbuhannya. Mengingat peran strategis posisi wanita dalam mengembangkan kepribadian anak, maka ia dituntut untuk selalu meningkatkan pengetahuan dan ketrampilannya agar mampu mewujudkan lingkungan yang kondusif, yang dapat merangsang tumbuh kembang anak secara optimal sesuai dengan usia anak, baik dalam aspek fisik, mental intelektual, sosial, maupun emosional. 


\section{LANDASAN TEORI}

Teori feminis sebagai alat kaum wanita untuk memperjuangkan hak-haknya, erat berkaitan dengan konflik kelas ras, khususnya konflik gender. Dalam teori sastra kontemporer, feminis merupakan gerakan perempuan yang terjadi hampir di seluruh dunia. Gerakan ini dipicu oleh adanya kesadaran bahwa hak-hak kaum perempuan sama dengan kaum laki-laki. Keberagaman dan perbedaan objek dengan teori dan metodenya merupakan ciri khas studi feminis. Dalam kaitannya dengan sastra, bidang studi yang relevan, diantaranya: tradisi literer perempuan, pengarang perempuan, pembaca perempuan, ciri-ciri khas bahasa perempuan, tokoh-tokoh perempuan, dan sebagainya. Teori feminis merupakan gerakan perempuan untuk menolak sesuatu yang dimarginalisasikan, direndahkan, dinomorduakan, dan disubordinasikan oleh kebudayan sosial, baik dalam bidang publik maupun bidang domestik. Feminisme lahir dengan tujuan mencari keseimbangan antara laki-laki dengan perempuan. Dengan lahirnya gerakan feminisme ini, masyarakat mulai terbuka dan sadar akan kedudukan perempuan yang inferior.

Perdebatan terpenting dalam teori feminis timbul sebagai akibat masalah wacana sebab perempuan sesungguhnya termarginalisasikan melalui wacana yang dikuasai oleh laki-laki. Pada dasarnya teori feminis dibawa ke Indonesia oleh A. Teeuw. Kenyataan ini pun sekaligus membuktikan bahwa teori-teori Barat dapat dimanfaatkan untuk menganalisis, dengan catatan bahwa teori adalah alat, bukan tujuan. Teori feminisme memiliki sejumlah varian yang memiliki perbedaan pandangan, khususnya dalam melihat asal-usul atau faktor penyebab subordinasi perempuan dan bagaimana mengatasi persoalan tersebut. Ritzer dan Goodman membuat klasifikasi berdasarkan tipe relasi gender yang meliputi perbedaan gender, ketimpangan gender, penindasan gender, dan penindasaan struktural.

Teori behaviorisme sangat erat kaitannya dengan perubahan tingkah laku sebagai hasil dari pengalaman. Dalam kehidupan ini tingkah laku atau behaviorisme adalah hal-hak yang dilakukan dalam kehidupan sehari-hari. Mulai dari anak-anak, remaja, hingga orang dewasa. Behaviorisme dapat menjelaskan segala kelakuan manusia secara saksama dan menyediakan program pendidikan yang efektif. Aliran behaviorisme sangat menekankan perilaku atau tingkah laku. Behaviorisme adalah teori perkembangan perilaku, yang dapat diukur, diamati dan dihasilkan oleh respon terhadap rangsangan. Tanggapan terhadap rangsangan dapat diperkuat dengan umpanbalik positif atau negatif terhadap perilaku kondisi yang diinginkan. 


\section{METODE PENELITIAN}

Dalam Penelitian ini merupakan penelitian kualitatif deskriptif dimana hasil penelitian mengenai nilai-nilai feminisme guru taman kanak-kanak Kecamatan BoneBone Kabupaten Luwu Utara. Maka untuk mencapai tujuan tersebut, peneliti ini menggunakan pendekatan kualitatif. Bungin $(2008 ; 68)$ menyatakan bahwa penelitian kualitatif adalah penelitian yang bersifat studi kasus, yang bertujuan untuk menggambarkan, meringkas berbagai kondisi, berbagai situasi, atau berbagai fenomena realitas sosial yang ada dalam masyarakat yang menjadi objek penelitian yang berupaya menarik realitas itu kepermukaan sebagai suatu ciri, karakter, sifat, model, tanda, atau gambaran tentang kondisi, situasi, ataupun fenomena tertentu. Teknik dalam penelitian ini sering disebut sebagai analisis isi (content analysis) yang cenderung mencatat apa yang tersirat dan yang tersurat. Teknik ini digunakan untuk mengumpulkan data yang bersumber dari dokumen dan arsip tentang pelaksanaan program Keluarga Berencana dalam studi kasus penelitian. Tehnik pengumpulan data yaitu observasi langsung, wawancara mendalam (in-depth interviewing), Mencatat Dokumen (Content Analysis), dan tehnik keabsahan data, Untuk menjamin validitas data yang akan dikumpulkan dalam penelitian ini, peneliti mengggunakan teknik informant review atau umpan balik dari informan (Milles dan Hubberman, 1984: 453). Selain itu peneliti juga menggunakan teknik triangulasi untuk lebih memvalidkan data (Patton, 1980: 100). Teknik triangulasi yang penulis gunakan dalam penelitian ini adalah triangulasi sumber, triangulasi metode, dan triangulasi teori. Pertama, triangulasi sumber, yakni mengumpulkan data sejenis dari beberapa sumber data yang berbeda.

\section{PEMBAHASAN}

Secara umum refresentasi nilai-nilai feminisme telah memperbaiki posisi perempuan dalam masyarakat dan pemberian hak perempun. Pandangan setiap masyarakata terhadap sosok seorang guru akan berbedah-bedah tegantung darimana kita mengambil sudut pandang. Seorang guru yang benar-benar mengabdi dan bertanggung jawab terhadap tugasnya maka akan dihormati dan memdapat kepercayan dari masyarakat untuk mendidik anak mereka menjadi anak lyang baik, berprestasi dan menjadi generasi penerus. Profesi menjadi guru di Indonesia memang masih terkesan prestise. Meskipun gaji guru pada kenyataannya masih rendah dan belum mencukupi kebutuhan hidup keluarga, namun karena citra guru adalah mulia maka banyak yang berebut ingin menjadi guru. Sebagaimana guru adalah pahlawan tanpa tanda jasa, 
tampaknya hal merupakan moto yang menjadi slogan sehingga dapat memotivasi bagi sebagaian para wanita untuk menentukan pilihan menjadi guru Taman Kanak-Kanak. Bagi sebagian orang menjadi guru Taman Kanak-Kanak adalah merupakan profesi yang membanggakan. Dengan berstatus sebagai guru Taman Kanak-Kanak maka status sosial menjadi terangkat. Bagi sebagian masyarakat status guru memang memiliki tempat terhormat, karena guru merupakan sosok yang dianggap panutan.

Harus dipahami bahwa sesuai dengan karakteristiknya yang suka meniru, di lingkungan keluarga orang tua (ayah dan ibu) adalah teladan yang akan ditiru oleh anak, apapun bentuknya. Tidak peduli itu benar atau salah, merugikan atau tidak merugikan orang lain, memalukan atau tidak memalukan. Hal ini dikarenakan ayah dan ibu adalah tokoh yang diidolakan, diunggulkan dan dianggap orang yang terbaik, terpandai, terbijaksana. Sehingga jangan heran apabila anak tidak saja akan meniru tutur kata, sikap dan perilaku orang tua yang baik-baik saja, tetapi juga yang buruk termasuk yang menurut standar kesopanan dan moral sangat memalukan. Menanamkan nilai-nilai moral dan agama pada anak perlu diberi porsi yang cukup agar kepribadiannya menjadi baik. Selain itu, anak juga perlu dikenalkan dengan konsep diri yang sebagai seorang anak, mampu membedakan baik buruk, serta antara yang hak denganyang bukan haknya. Positif serta kedisiplinan, karena ini akan berimbas pada perilaku di masa remajanya. Terutama dalam hal bisa tidaknya ia memandang dirinya secara positif serta ketaatan terhadap segala bentuk aturan, adat istiadat dan budaya setempat, tempat dimana ia hidup dan berinteraksi dengan orang lain maupun lingkungannya. Dengan tertanamnya nilainilai moral dan agama secara baik pada anak, anak akan mampu menfilter pengaruh buruk dari luar. Mampu memilih hal yang pantas dan tidak pantas untuk dilakukan. Oleh karenanya, anak siap untuk dididik menjadi generasi penerus bangsa yang dapat diharapkan perannya dalam pembangunan menuju kebesaran dan kejayaan bangsa di kemudian hari. Sementara itu bagi keluarga, jelas akan membawa nama harum keluarga dan orang tua karena perilaku dan tindakannya yang benar-benar terpuji.

\section{SIMPULAN}

Pada bagian penutup ini dapat disimpulkan nilai-nilai feminisme guru taman kanak-kanak Kecamatan Bone-Bone Kabupaten Luwu Utara (suatu kajian dalam pewrspektif gender) memberikan dampak yang progresif yaitu : 
1. Refresentasi Nilai-Nilai Feminisme Guru Taman kanak-kanak, dengan adanya nilainilai feminisme yang dimiliki oleh guru perempuan maka mereka mampu membentuk karakter peserta didiknya, menanamkan nilai-nilai moral sehingga peserta didik mengalami progres yang bersifat positif. Sehingga masyarakat memiliki harapan lebih terhadap guru-guru yang ada di Kecamatan Bone-Bone terkhususnya di Taman Kanak-Kanak yang ada di Kecamatan Bone-Bone Kabupaten Luwu Utara menjadikan anak mereka menjadi generasi penerus yang bermoral dan guru-guru ini mampu bertanggung jawab dengan tugas mereka.

2. Partisipasi Perempuan Dalam Proses Penanaman Nilai-Nilai di Taman Kanak-Kanak sebagai perempuan mereka mampu menanamkan nilai-nilai dengan berbagai bentuk kepada anak-anak didiknya, melatih anak-anak yang masih membutuhkan dominasi peran orang dewasa, suka mengulangi dan harus dibiasakan, suka meniru dan senang dengan bentuk-bentuk penghargaan langsung seperti diberi permainan dan pujian. Dengan sifat-sifat kewanitaan dan keibuannya seorang guru taman kanak-kanak mampu membentuk karakterr anak didiknya, mengembangkan keterampilan dasar dan dasar-dasar pemahaman dalam semua bidang mampu memenejemen kelas. Dalam proses penanaman nilai-nilai moral pada anak, pendidikan moral disisipkan secara terstruktur dalam proses pembelajaran yang dilaksanakan.

\section{DAFTAR PUSTAKA}

Bachri, Bachtiar S. (2010). "Meyakinkan Validitas Data Melalui Triangulasi Pada Penelitian Kualitatif". Jurnal Teknologi Pendidikan, Vol.10 No.1. Surabaya: Universitas Negeri Surabaya.

Dimyanti \& Mudjiono. (2002). Belajar dan Pembelajaran. Jakarta: PT Rineka Cipta.

Echols, John M. dan Hassan Shadily (1983). Kamus Inggris Indonesia. Jakarta:

Eviota, Elizabeth, (1992). The Political Economy of Gender. London: Zed Books, Ltd.

Fakih, Mansour, (1996). Analisis Gender dan Transformasi Sosial. Yogyakarta: Pustaka Pelajar..

Garis-garis Besar Program Kegiatan Belajar Taman Kanak-Kanak (1994). Jakarta. Depdiknas.

Gettwicki, Carol. (2007). Developmentally Appropriate Practice: Curriculum and Development in

Gramedia. Cet. XII. 
Gutama,dkk. (2005). Mewujudkan Pendidikan Anak Usia Dini yang Holistik. Seminar dan Lokakarya Nasional 2005 PendidikanAnakUsiaDini, kampus UGM 14-16 Nopember 2005.

Gutama. (2002). Pentingnya Pendidikan Anak Usia Dini. Depdiknas: direktorial Pendidikan Luar Sekolah

Haryanto, Sindung. (2012). Spektrum Teori Sosial dari Klasik hingga Postmodern. Yogyakarta: Ar-Ruzz Media.

Heraty, Toeti Noerhadi, (2002). "Perihal Rekayasa dan Bias Gender". Dalam

Jalal, Fasli. 2004. Potret Pengasuhan, Pendidikan dan Pengembangan Anak Usia Dini. Jakarta: Forum Padu.

Jamaris, Martini. (2005). Perkembangan dan Pengembangan Anak Usia TK. Jakarta: Grasindo.

Kamalfachri, "Teori Behaviorisme" ,dalam Website file:///H:/Teori behaviorisme dan permasalahn/Kamalfachri. Weblog.htm, data diakses pada tanggal 2 Juni 2011.

Latief, Dochak, (2006), Etika Bisnis: Antara Norma dan Realitas, Muhammadiyah Universitas Press, Surakarta.

Lutfian, Alvi, (2004). "Perupa Perempuan Yogyakarta Tinjauan Dalam Perspektif Gender”. Dalam EKSPRESI Seni dan Perempuan Jurnal ISI Yogyakarta.

Mohammad Ali dan Mohammad Asrori, (2010). Judul : Psikologi Remaja (Perkembangan Peserta Dididik). Penerbit PT Bumi Aksara : Jakarta.

Moleong, Lexy J. (2002). Metodologi Penelitian Kualitatif. Bandung: Remaja Rosdakarya.

Mosse,Julia Cleves. (2007). Gender \& Pembangunan. Yogyakarta: Pustaka Postmodern. Yogyakarta: Ar-Ruzz Media.

Quraisy, H., \& Nawir, M. (2015). Kesetaraan Gender Pegawai Dinas Pertanian. equilibrium, 3(1), 77-86.

Sugihastuti \& Suharto. (2002). Kritik Sastra Feminis : Teori dan Aplikasinya Jogjakarta: Pustaka Pelajar.

Susanti, B.M, (2000). "Penelitian Tentang Perempuan Dari Pandangan Androsentris ke Perspektif Gender". Dalam EKSPRESI Dari Bias lelaki menuju Kesetaraan Gender Jurnal ISI Yogyakarta.

Vioranova.blogspot.com 2013

Whelehan, Imelda, (1993), Modern Feminist Thought: From the Secondwaveton "Post Modernism”. New York: New York University Press 